\title{
Cyclophosphamide Neutralization in Wastewaters Using an Asymmetric Current Density Electrochemical Microreactor
}

\author{
HARALD BARZAN", ERIKA DIANA ARDELEAN"\#, GABRIELA ALINA DUMITREL ${ }^{2 *}$, \\ DANIEL HĂDĂRUGĂ ${ }^{2}$, PETRU BÂRZAN ${ }^{3}$, GABRIELA BÂRZAN ${ }^{3}$, DAVID COMANICIU ${ }^{4}$, \\ VALENTIN ORDODI ${ }^{2,3}$ \\ ${ }^{1}$ Babeș-Bolyai University, 7-9 Universității Str., 400084, Cluj-Napoca, Romania \\ ${ }^{2}$ Politehnica University of Timişoara, 2 Victoriei Sq., 300006, Timişoara, Romania \\ ${ }^{3}$ SC Natural Ingredients R\&D SRL, 10/1Tabacari Str., 505200, Fagaraș, Romania \\ ${ }^{4}$ Lucian Blaga University Sibiu, 10 Victoriei Blvd., 550024, Sibiu, Romania
}

\begin{abstract}
Alkylating antineoplastic agents used in modern oncological treatments constitute noteworthy environmental hazards with a great long-term impact on human health. This paper introduces an asymmetric current density electrochemical microreactor specifically designed to neutralize alkylating cytostatic drugs from wastewaters. The reactor is based on the principle of anodic electrooxidation (AEO) and on chemical oxidation via anode-generated chlorine reactive species (CRS). The design of this electrochemical reactor facilitates very good (approx. 99\%) neutralization yields for the substance used in this study.
\end{abstract}

Keywords: electrochemical reactor, asymmetric current density, cytostatic drug waste, electrooxidation

Spectacular progress in the treatment of oncohematological diseases via bone marrow transplants has ushered in the widespread use of large quantities of alkylating antineoplasic agents. This class of therapeutic drugs, of which cyclophosphamide is a member, displays carcinogenic, teratogenic and mutagenic properties. Public and private health institutions that offer oncological treatments generate significant quantities of wastewater that contain this type of pollutant, which, if not disposed of properly, can build up in the environment and become hazardous to human and animal health $[1,2]$.

At the time of writing, the legislation in Romania stipulates that elimination of these waste materials should be done by incineration, but incineration is a very energy-inefficient process which requires special filters for combustion product evacuation (which can contain dioxins, furanes and gases such as $\mathrm{CO}, \mathrm{CO}_{2}, \mathrm{HCl}, \mathrm{SO}_{2}, \mathrm{NO}_{\mathrm{x}}$, etc) and is difficult to apply for very large quantities of liquid waste such as wastewater. Internationally, there have been many proposed methods for inactivating cytostatic drugs in wastewater, but usually they imply the use of concentrated acids and bases and are cumbersome to deploy in a hospital environment $[3,4]$.

The scope of this study is to design and build an asymmetric current density electrochemical reactor adequate for cyclophosphamide neutralization, relying on anodic electro-oxidation and chemical oxidation via chlorine reactive species $[5,6]$.

\section{Experimental part}

\section{Materials and methods}

The asymmetric current density electrochemical microreactor is comprised of a $55 \mathrm{~mm}$ high, $60 \mathrm{~mm}$ diameter Plexiglas cylinder with a small nozzle on the bottom side, which serves to fill and drain the liquid content of the cylinder. The working volume of the reactor is $100 \mathrm{ml}$. Covering the cylinder is a Plexiglas lid that fits most of the working components: 8 thick graphite bars (constituting the anode), the stainless steel cathode, the mechanical stirrer and its motor, the compressed air intake and electrolysis gas product evacuation tubes, and a sampling nozzle for live sample collection. The lid also sports two conductometric sensors: one to detect whether the volume of the liquid has reached the working volume of the reactor and another one to stop the intake pump if the volume of the liquid exceeds the maximum allowed volume of the cylinder.

The cathode is made of stainless steel and has a useful surface of $3.6 \mathrm{~cm}^{2}$, and the anode is comprised of 8 graphite bars with a total of $45.2 \mathrm{~cm}^{2}$ useful surface.The reactor is designed to have an anode surface significantly larger than the cathode surface, producing a significantly higher cathode current density, thus favoring anodic oxidation processes and the production of reactive chlorine species and hypochlorite ions. The working current is 1A. Figure 1 presents the electrochemical reactor assembly, the layout of the electrodes and mecanical stirrer [7,8].

The diagram in figure 2 presents all the working components of the microreactor. 


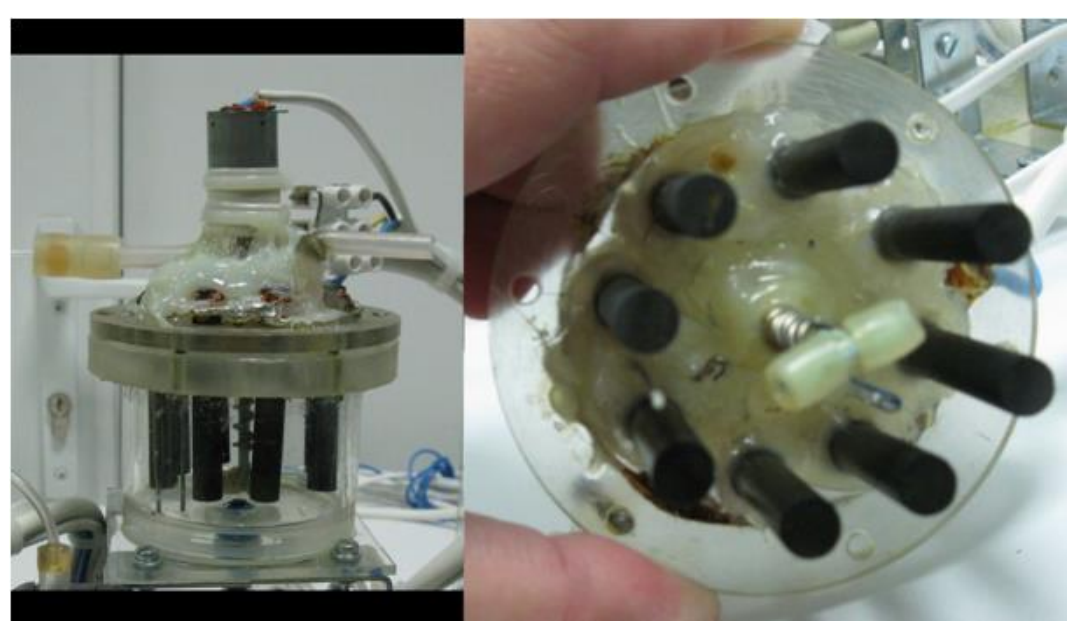

Fig. 1. Asymmetric current density electrochemical microreactor

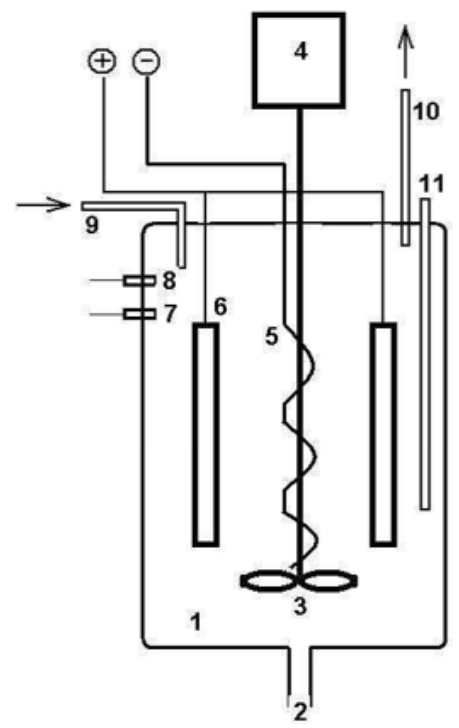

Fig. 2. Asymmetric current density electrochemical microreactor diagram:

1 - reaction vessel, 2 - fill/drain nozzle, 3 -mechanical stirrer, 4 - mechanical stirrer motor, 5 - spiraling stainless steel cathode, 6 - graphite anodes, 7 - working volume sensor, 8 - overfill sensor, 9 - compressed air intake,

10 - electrolysis gas product evacuation tube, 11 - sampling nozzle

The cyclophosphamide-containing sample is introduced in the microreactor through the bottom nozzle (figure 2. (2)) using a peristaltic pump controlled by the signal coming from the volume sensor (figure 2. (7)). When the reactor is full, the signal from the volume sensor stops the pump and starts the electrolysis reaction. The duration of the electrolysis reaction is 30 minutes with a constant current of $1 \mathrm{~A}$. After the reaction, the microreactor is drained through the bottom nozzle. The microreactor is fitted with a compressor which generates a flow of compressed air ( $500 \mathrm{~mL} / \mathrm{minute})$ through the reaction medium, pushing out the electrolysis gas product, which would otherwise have a corrosive effect on the reactor.

\section{Synthetic cyclophosphamide-containing wastewater neutralization}

Cyclophosphamide $\left(\mathrm{C}_{7} \mathrm{H}_{15} \mathrm{Cl}_{2} \mathrm{~N}_{2} \mathrm{O}_{2} \mathrm{P}\right)$ is a chlormethine derivative and an alkylating antineoplasic agent used in the treatment of several oncological diseases: lymphoma, multiple myeloma, neuroblastoma, soft tissue sarcoma, breast and testicular tumors and some forms of leukemia are common examples. High doses of cyclophosphamide are administered in intermittent mono-chemotherapy: $40 \mathrm{mg} / \mathrm{kg} /$ day. Pharmacokinetics data suggests that $30 \%$ of administered cyclophosphamide is excreted in its non-metabolized form, via renal excretion, which gives the urine of the patients a high concentration of this cytostatic drug. Pharmacological data has showed that cyclophosphamide has leukemogenic and teratogenic effects in chronic exposure, even at low doses.

Cyclophosphamide is a white crystalline powder mildly soluble in water. For this study, a synthetic wastewater preparation was made by dissolving $100 \mathrm{mg}$ of cyclophosphamide in $100 \mathrm{ml} 5 \% \mathrm{NaCl}$ solution. The determination of cyclophosphamide concentration before and during the electrolysis reaction was made using an Agilent 1100 Series high-performance liquid chromatography (HPLC) instrument, fitted with an analytic-grade reverse-phase C18 column (Zorbax SB-C18). Mobile phase consisted of $20 \%$ acetonitrile and $80 \%$ phosphate buffer $0.1 \mathrm{M}$ with $\mathrm{pH}=6$ at $25^{\circ} \mathrm{C}$. The detector is a UV-VIS spectrophotometer set at $200 \mathrm{~nm}$ wavelength. The chromatogram acquisition duration was 23 minutes. In these conditions, the retention time of cyclophosphamide is 19.1 minutes $[9,10]$. 


\section{Results and discussions}

The experimental data shows that the electrochemical microreactor is suitable for cyclophosphamide electrodegradation within a reasonable time frame and with relatively low energy requirements. The putative mechanism for this electrodegradation cascade is presented in figure 3.

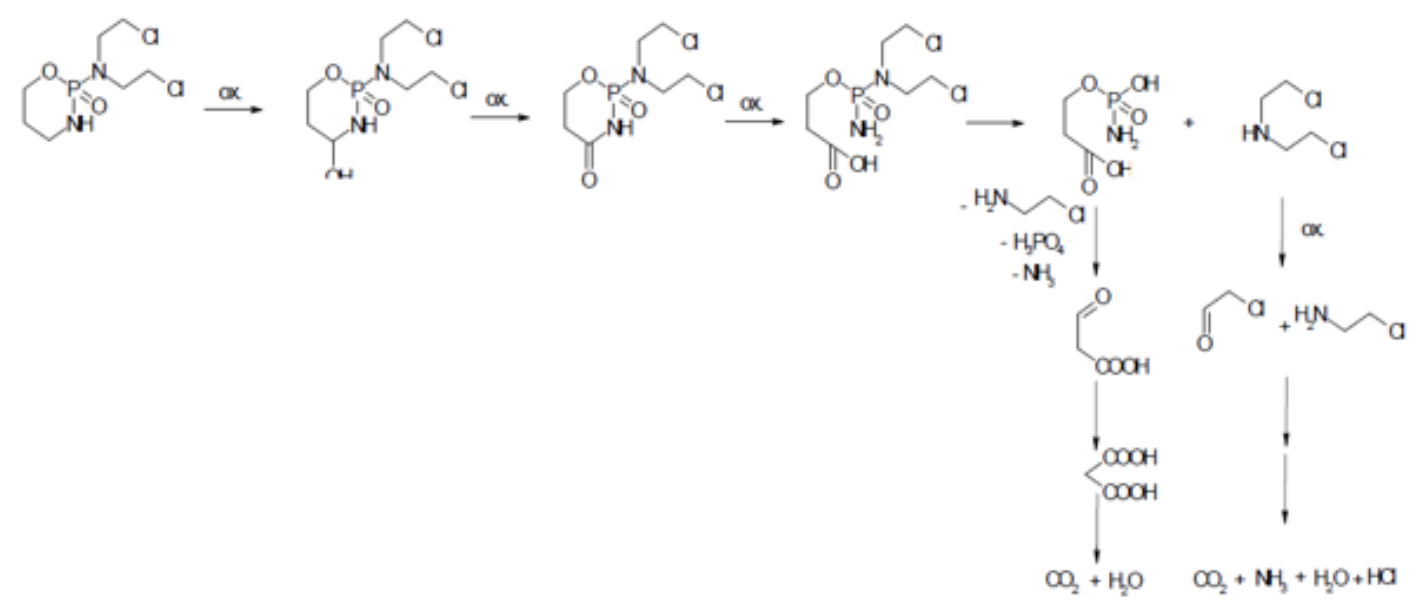

Fig. 3. Cyclophosphamide degradation via electrochemical oxidation

The synthetic wastewater sample containing $100 \mathrm{mg} / \mathrm{dL}$ cyclophosphamide has undergone electro-degradation in the experimental microreactor for 30 minutes at $1 \mathrm{~A}$ working current. The wastewater cyclophosphamide concentration was sampled during the electrochemical treatment and the samples were analyzed using the HPLC method, with results displayed in table 1 .

Table 1

HPLC ANALYSIS OF CYCLOPHOSPHAMIDE-CONTAINING SYNTHETIC WASTEWATER DURING TREATMENT

\begin{tabular}{ccc}
$\begin{array}{c}\text { Sampling time } \\
\text { (minutes) }\end{array}$ & $\begin{array}{c}\text { Cyclophosphamide peak } \\
\text { area } \\
\text { [mAU*s] }\end{array}$ & $\begin{array}{c}\text { Cyclophosphamide } \\
\text { concentration } \\
\text { (mg/dl) }\end{array}$ \\
\hline 0 & 2626 & 100 \\
1 & 1669 & 69 \\
2 & 713 & 29.5 \\
3 & 240 & 10 \\
4 & 78 & 4.6 \\
5 & 14 & 0.8 \\
10 & 6 & 0.3 \\
15 & $<$ LOD & - \\
30 & <LOD & - \\
\hline
\end{tabular}

In table 1 the drop in cyclophosphamide concentration can be observed during electrolysis, dropping below the limit of detection (LOD) of the HPLC instrument after 10 minutes. In figure 4 the graph of the concentration is shown with respect to time, closely approximating a decaying exponential function (Equation 1):

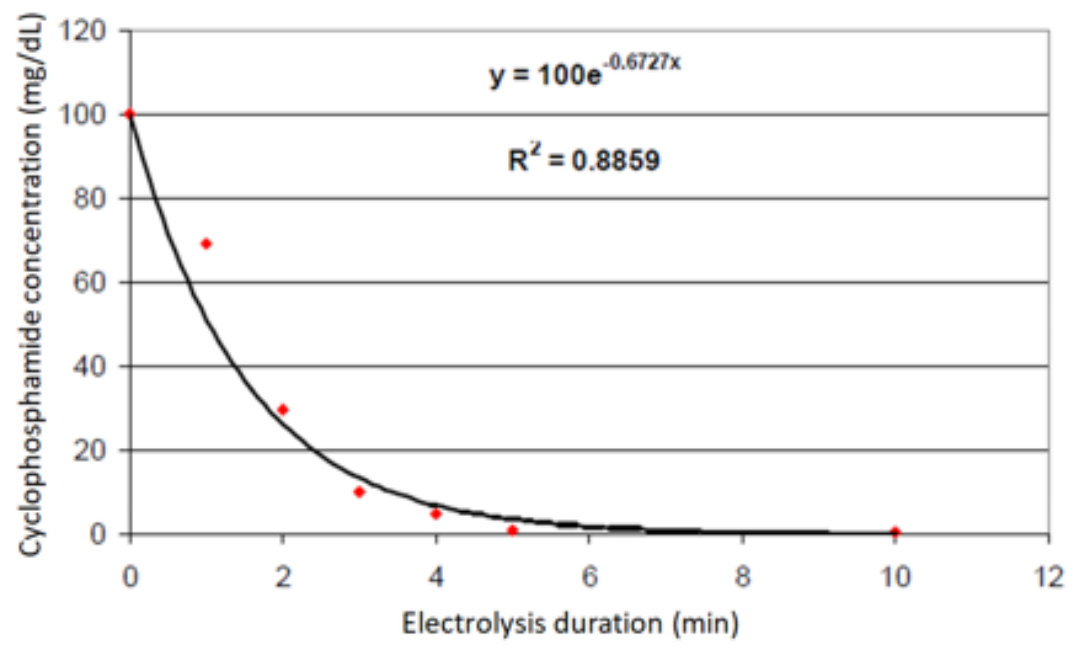

Fig. 4. Cyclophosphamide concentration in synthetic wastewater during the electro-degradation process 
The coefficient of correlation value $\left(R^{2}=0.8859\right)$ indicates that equation (1) reliably approximates the evolution of the cyclophosphamide concentration during electro-degradation [11].

The yield of the degradation (2) was calculated using the initial concentration $\left(C_{i}\right)$ of the synthetic wastewater before treatment and the final concentration $\left(C_{f}\right)$ at 10 minutes into the degradation treatment, right before the concentrations drops below the limit of detection:

$$
\eta_{\text {cyclophosphamide }}=100-\frac{C_{i}}{C_{f}} * 100=100-0.03=99,7 \%
$$

\section{Conclusions}

The proposed asymmetric current density electrochemical microreactor is suitable for cyclophosphamidecontaminated wastewater treatment. Conceptually, this type of reactor has the advantage of facilitating the type of reactions we are interested in - anodic electro-oxidation. The present paper justifies building the reactor at a larger scale to be used in cytostatic drug contaminated wastewater treatment.

\section{References}

1.HIROSE, J., KONDO, F., NAKANO, T., KOBAYASHI, T., HIRO, N., ANDO, Y., TAKENAKA, H., SANO, K. Chemosphere, 60, no. 8, 2005, p. 1018

2.INTERNATIONAL AGENCY FOR RESEARCH ON CANCER, IARC Monograph on the Evaluation of Carcinogenic Risks to Humans: Listof IARC Evaluations. IARC Lyon, France, 1996

3.***HG 1862/2005 pentru aprobarea proiectului Incinerarea deșeurilor periculoase și sterilizarea deșeurilor provenite din activități medicale

4.VASILESCU V.G., VASILESCU E., Deșeurile medicale - generare, gestionare și eliminare ecologică, Buletinul AGIR nr. 1/2017, 275-279

5.MIRICA, M. C., PREDA M., MIRICA N., Teoria reactoarelor electrochimice cu densitãti de curent asimetrice, Editura Mirton, Timisoara, 2006, p.109

6.ORDODI V.L., DUMITREL G.A., ALEXANDRA GRUIA A.T., IACOB M., JINESCU G., PERJU D.M.Rev. Chim. (Bucharest), 61, no. 9, 2010, p.857

7.PERJU, D, SUTA, M, RUSNAC, C, BRUSTUREAN, GA, Rev. Chim.(Bucharest), 54, no.3, 2003, p. 250

8.KOBAYASHI, T., HIROSE, J., SQNO, K., HIRO, N., IJIRI, Y., TAKIUCHI,H., TAMAI, H., TAKENAKA, H, TANAKA, K., NAKANO, T., Chemosphere,72, no. 4, 2008, p. 659

9.KERWICK, M.I., REDDY, S.M., CHAMBERLAIN, A.H.L., HOLT, D.M.,Electrochim. Acta, 50, 2005, p.5270

10.SCIALDONE, O., RANDAZZO, S., GALIA, A., SILVESTRI, G., WaterRes., 43, 2009, p. 2260

11.BRUSTUREAN G.A, TODINCA T., PERJU D., CARRE J., RUSNAC C.,Rev. Chim. (Bucharest), 58, no. 12, 2007, p.1268

Manuscript received: 22.04 .2019 